\title{
The Question of Grammatical Equivalence in Translation
}

\author{
Siti Sudartini \\ State University of Yogyakarta
}

\begin{abstract}
.
This study is concerned with three aspects of grammatical equivalence occurring in translation, namely, person, tense and voice. In particular, this study tries to answer some questions related to the notion of grammatical equivalence in English-Bahasa Indonesia translation related to the categories of person (pronoun), tenses, and voice.

This study is a descriptive qualitative one which tries to describe and delineate the phenomenon of translation naturally without the intervention of an experiment or an artificially contrived treatment. This kind of study requires a holistic perspective of the research area in order to gather as much information as possible and to avoid any manipulation or interference in the study context. The results of the study have shown the followings. Firstly, most of the English pronouns with person reference are translated by the personal pronouns in Bahasa Indonesia, some are not translated by the personal pronouns in Bahasa Indonesia since their meaning are considered known from their context, and some other are not translated by personal pronouns but rather by repeating the noun reference. Secondly, the category of tense in English is presented morphologically by changing the verb forms whereas in Bahasa Indonesia it is presented lexically by adding words indicating the time relation of the event presented by the verb. Thirdly, both English and Bahasa Indonesia have the category of voice but they do not always use this category with the same frequency. The active forms in English are not always translated into active forms in Bahasa Indonesia, and vice versa.
\end{abstract}

Key words: question, grammatical equivalence, English, translation 


\section{A. : Introduction}

It is generally agreed so far that meaning is very important in translation (Catford, 1965: 35). Indeed, translation has often been defined with reference to meaning; a translation is said to have the same meaning as the original or a translation should not sound like a translation. This meaning is in fact conventionally packaged in the languages, either the source or the target language. Every translator needs also to consider the fact that each language has its own distinctive forms to represent meaning. It is also important for translators to realize that not all of the elements of a language have equivalent forms in another language. Therefore, finding the equivalence may be considered as one of the problems which are commonly faced by translators.

Due to Baker (1992: 5) there are five levels of equivalence, namely, 1) equivalence at word level; 2) equivalence above word level, 3) grammatical equivalence, 4) textual equivalence, and 5) pragmatic equivalence. This particular study merely concerns with the third level of equivalence, i.e. the grammatical equivalence. There are a variety of grammatical categories, which may or may not be expressed in different languages. Baker mentions five categories that commonly lead to difficulties in finding the equivalence during the process of translation. They are Number, Gender, Person (the system of pronoun), Tense, and Voice. This particular study, however, focuses on three of those grammatical categories, namely, the category of Person, Tense, and Voice. Translation here indeed involves two languages, namely, the source and the target languages. In this particular study, the source language is English for it may be the most translated language in the world. The target language is Bahasa Indonesia since it is our national language which is used as the medium. of instruction of all of culture, science; and technology in our country.

\section{B. Grammatical Equivalence in Translation}

\section{B.1 The Notion of Translation}

There a variety of definitions related to the term translation. In Merriam Webster Dictionary, as quoted by Zuchridin (1989: 1), to translate is to change a text from one state or form to another, or to turn a text into one's own or another language. Translation may also be defined as a product as well as a process. The 
following is the definition of the word translation written in The Concise Oxford English Dictionary.

translation $n .1$ the act or an instance of translating. 2 a written or spoken expression of the meaning of a word, speech, book, etc. in another language.

Hatim and Munday (2004:6) also propose three notions on the word translation as,

1. The process of transferring a written text from SL to TL, conducted by a translator or translators, in a specific socio-cultural context.

2. The written product, or TT, which results from that process and which functions in the socio-cultural context of the TL.

3. The cognitive, linguistic, visual; cultural and ideological phenomena which are an integral part of 1 and 2 .

Schaffner in Mona Baker (2001: 3) states that translation is conceived primarily as a process of intercultural communication, whose end product is a text which is capable of functioning appropriately in specific situations and contexts of use. What makes translation complicated, then, is the diversity or the lack of oneto-one correlation between form and meaning, considering the fact that each language has its own distinctive forms for representing the meaning. $\mathrm{N} \mathrm{e} \mathrm{w} \mathrm{m} \mathrm{a} \mathrm{r} \mathrm{k}$ (1988: 32), therefore, mentions that translation is the superordinate term for converting the meaning of any utterance of any source language to the target language. In doing this, translators need to consider mainly the content of the text rather than the form. Papegaaij and Schubert in Newmark (1988: 11) also state that to translate means to express in another language the content of a given text. They say that the objective of translation is to replace the form and to preserve the content of the text. Translation is thus form manipulation with reference to content.

These definitions suggest translators to consider meaning as the variable of greatest importance in translation. Therefore, in translation the same meaning may have to be expressed in another language by a very different form. To translate the form of one language literally into the corresponding form in another language would often change the meaning. This is to say that meaning must have priority over form. Translators, however, need to start off with the direction from meaning to form not the other way around. It is the translators' duty to reproduce the text in the target language which merely contains the similar meaning of the original. In doing so, it is the problem of finding the equivalence that may be the central concern in translation process. 


\section{B.2 Grammatical Equivalence in Translation}

Hatim and Munday (2004: 40-42) mention that the term equivalence in translation could be divided into two main divisions, i.e. the formal equivalence and dynamic equivalence. The former refers to a relationship which involves the purely 'formal' replacement of one word or phrase in the SL by another in the TL, while the latter is used whenever in the translators' judgement a form of words that is not sufficiently transparent in the TT is likely to pose a threat to comprehensibility and therefore intervention on the part of the translator becomes inevitable. This division of the term equivalence is actually referring back to the principles of translatability and comprehensibility in translation.

Baker (1992) however, has made classification on the notion of equivalence in translation. She mentions five levels of equivalence and one of them is grammatical equivalence. Baker (1992: 83) states that grammar can be said to be the set of rules which determine the way in which units such as words and phrases can be combined in a language and the kind of information which has to be made regularly explicit in utterances. Baker claims that differences in the grammatical structures of the source and the target languages often result in some change in the information content of the message during the process of translation. This change may take the form of adding to the target text information which is not expressed in the source text or omitting information specified in the source text (Baker, 1992: 86-109). Baker, moreover, mentions some grammatical categories which are intended to illustrate the kinds of difficulties that translators often encounter. because of differences in the grammatical structures of the source and target languages. Those are the categories of Number, Gender, Person, Tense and Aspect, and Voice. This particular study, however, will-not concern all of those categories. It mainly discusses three of them, namely the categories of Person, Tense and Voice in English-Bahasa Indonesia Translation.

\section{Grammatical Categories of English and Bahasa Indonesia Translation \\ C.1 Category of Person}

The category of person relates to the notion of participant roles. English as the source language has three types of pronouns with person reference; namely, the personal pronouns, reflexive pronouns, and possessive pronouns. These pronouns have distinctions of person: the first person referring to the speaker (I or We); the 
second person referring to the person(s) addressed (you); and the third person referring to one or more other persons or things (he/she/it/they). The personal pronouns have two sets of case-forms: the subjective and the objective.forms. Whereas the reflexive pronouns replace a co-referential noun phrase, normally within the same finite clause and the possessive ones combine genitive functions with pronominal functions. The following Table 1 illustrates these three types of English pronouns stated by Quirk and Greenbaum (1973: 102).

\section{Table 1. English Pronouns}

\begin{tabular}{|c|c|c|c|c|c|c|c|}
\hline & \multirow{2}{*}{\multicolumn{2}{|c|}{. }} & \multicolumn{2}{|c|}{ Personal Pronouns } & \multirow{2}{*}{$\begin{array}{l}\text { Reflexive } \\
\text { Pronouns }\end{array}$} & \multicolumn{2}{|c|}{ Possessive Pronouns } \\
\hline & & & $\begin{array}{l}\text { Subj. } \\
\text { Case }\end{array}$ & $\begin{array}{l}\text { Obj- } \\
\text { Case }\end{array}$ & & $\begin{array}{l}\text { Determiner } \\
\text { Function }\end{array}$ & $\begin{array}{l}\text { Nominal } \\
\text { Function }\end{array}$ \\
\hline \multirow[t]{2}{*}{$1^{\text {st }}$} & \multicolumn{2}{|l|}{ Singular } & $I$ & me & Myself & my & mine \\
\hline & \multicolumn{2}{|l|}{ Plural } & we & Us & ourselves & our & ours \\
\hline \multirow{2}{*}{$2^{\text {nd }}$} & \multicolumn{2}{|l|}{ Singular } & \multirow{2}{*}{\multicolumn{2}{|c|}{ You }} & Yourself & & \\
\hline & \multicolumn{2}{|l|}{ Plural } & & & yourselves & your & yours \\
\hline \multirow[t]{4}{*}{$3^{\text {nd }}$} & \multirow[t]{3}{*}{ Singular } & Masc. & he & him & Himself & \multicolumn{2}{|l|}{ his } \\
\hline & & Fem. & she & her & Herself & her & hers \\
\hline & & Non-p & It & & Itself & its & \\
\hline & \multicolumn{2}{|l|}{ Plural } & they & them & themselves & their & theirs \\
\hline
\end{tabular}

Bahasa Indonesia, however, only has one type of pronoun with person reference, which is the personal pronoun. This kind of pronoun also has distinctions of the first person (the speaker), the second person (the person spoken to), and the third person (the person being spoken of (Moeliono, 1988:-172). In Bahasa Indonesia, there is not only a distinction of singular and plural forms but also a distinction of exclusive and inclusive forms (especially in the first person plural form). The division of this division can be seen in Table 2 . 
Táble 2. Personal Pronouns of Bahasa Indonesia (Moeliono, 1988: 172)

\begin{tabular}{|l|l|l|c|c|}
\hline \multirow{2}{*}{ Person } & \multicolumn{3}{|c|}{ Meaning } \\
\cline { 2 - 5 } & \multicolumn{1}{|c|}{ Singular } & \multicolumn{2}{|c|}{ Plural } \\
\cline { 2 - 5 } $\begin{array}{l}\text { First } \\
\text { Person }\end{array}$ & $\begin{array}{l}\text { saya, aku, daku, ku-, } \\
\text { ku }\end{array}$ & & kami & kita \\
\hline $\begin{array}{l}\text { Second } \\
\text { Person }\end{array}$ & $\begin{array}{l}\text { engkau, kamu, anda, } \\
\text { dikau, kau-, -mu, } \\
\text { saudara }\end{array}$ & $\begin{array}{l}\text { katian, kamu } \\
\text { (sekalian), anda } \\
\text { sekalian }\end{array}$ & & \\
\hline $\begin{array}{l}\text { Third } \\
\text { Person }\end{array}$ & $\begin{array}{l}\text { ia, dia, beliau, } \\
\text {-nya }\end{array}$ & mereka, -nya & & \\
\hline
\end{tabular}

\section{C.2 Category of Tense}

The word tense stands for a verb form or series of verb forms. used to express a time relation. Tenses may indicate whether an action, activity, or state is past, present, or future. Hornby (1975: 78-79) notes that English verbs have not only two simple tenses which are called the Simple Present and Simple Past but also many compound tenses which are made by combining two or more verb forms. These combinations may be concerned with time, especially those with parts of the verbs "be" and "have". There are actually 12 tenses in his lists: 1) Simple Present Tense, 2) Present Progressive Tense, 3) Simple Past Tense, 4) Past progressive Tense, 5) Future Tense Non-Progressive, 6) Future Progressive Tense, 7) Present Perfect Tense Non-Progressive, 8) Present Perfect Progressive Tense, 9) Past Perfect Tense, 10) Past Perfect progressive Tense, 11) Future Perfect Tense NonProgressive, and 12) Future Perfect Progressive Tense.

What make the English tenses complicated is the fact that the term present, past and future within these tenses do not actually refer to the present time, past time and future time. In Bahasa Indonesia, on the other hand, there are no changes of verb forms in representing the tense category. Bahasa Indonesia does not indicate the category of tense morphologically but rather lexically by adding a particular word that indicates the tense: Words which are usually used to express tense in Bahasa Indonesia are 'sudah or telah' (to express the idea of past tenses), 'sedang'(to indicate present tenses), and the word 'akan'(for future tenses). 


\section{C.3 Category of Voice}

Frank(1972:55) states that voice in English grammar refers to the active and passive use of a verb. He also notes that the English people use the active voice more often than the passive voice since they prefer to make a direct statement of an action. The passive voice is used when the greater emphasis is to be placed on the 'event' than on the 'actor', or when the 'doer' of an action is unimportant or is unknown.

In Bahasa Indonesia, however, there are four types of passive sentences as quoted by Dardjowidojo, in Purwo (1986: 59). Those are: 1) the passive sentences which express intentional acts (commonly marked by the use of prefix $d i-$ ), 2) the passive sentences which express unintentional acts (commonly marked by the use of prefix ter-),3) the adversative passive sentences (that commonly marked by the use of affix $k e$-and an in the sentence), and 4) the passive sentences formed by the use of $k e$-an meaning dapat di + verb.

\section{Research Methodology}

The main approach underlying this particular study is descriptive qualitative which tries to describe and delineate the phenomenon of translation naturally without the intervention of an experiment or an artificially contrived treatment. This kind of study requires a holistic perspective of the research area in order to gather as much as information as possible and to avoid any manipulation or interference in the study context. The population of this study is eight books of social sciences together with the translation. The sample of the analysis is taken from each of the books by using the proportional random sampling technique. The main technique used in analyzing the research data is content analysis.

\section{E. Result, and Analysis}

This particular study, the writer took samples from eight books of social sciences both the original and the translation. The books are: 1) General Linguistic: An Introductory Survey, 2) Language, 3) Theory of Literature, 4) Content Analysis: An Introduction to Its Methodology, 5) Discourse Analysis, 6) A Reader's Guide to Contemporary Literary Theory, 7) The Comparative Study of Religions, and 8) Sociology of Religion. 


\section{E.1 Analysis on the Category of Person}

The result of the analysis on the person category found in the eight books has shown that most of the English pronouns $(79,36 \%)$ with person reference are translated or expressed by the personal pronouns of Bahasa Indonesia. Some pronouns (around $11,11 \%$ ) are not translated by the personal pronouns in Bahasa Indonesia since their meaning are considered known from their context, and some others are not translated by using the personal pronouns but rather by repeating the noun reference mainly when these pronouns are used to refer to the non-personal or impersonal noun. The following are some examples of the not translated English personal pronouns and the use of noun repetition in translating the English personal pronouns.

1) The speaking Jill in our story availed herself of just such an arrangement. (Text . II)

Jill yang berbicara dalam kisah itu memanfaatkan upaya seperti itu.

2) It would not have been possible for "grammarians" to bluff a large part of our speech community, and they would not have undertaken to do so, if the public had not been ready for the deception. (Text II)

Tidak akan mungkin "ahli-ahli grämatika" mengelabui sebagian besar masyarakat bahasa kita, dan tidak akan berusaha berbuat demikian, seandainya masyarakat tidak bersedia dikelabui.

3) The nature of linguistic abstractions has already been discussed, and it was pointed out that at any level of analysis they may be of different degrees of generality,...(Text I)

Kita telah membahas hakikat abstraksi linguistis dan melihat bahwa, pada tatanan analisis manapun, abstraksi itu mungkin mempunyai kadar keumtuman yang berbeda-beda,...

4) A good deal of the particular function of some words must be stated in terms of their relations with other words in the sentences of which they typically form a part.

Sebagian besar dari fungsi khusts beberapa kata harus dinyatakan berdasarkan hubungan kata-kata itu dengan kata-kata lain dalam kalimat yang dimasukinya. 
The other problem of translating English personal pronouns lies on the use of the first plural form of "we" which can be translated either into kami or kita in Bahasa Indonesia depending upon whether the second person or the person being addressed is included or excluded. The word kami is used when the person addressed is excluded in the speaker statement (idea) whereas the word kita s used when the person addressed is included in the speaker's statement. The following are examples of the use of kami and kita in translating the English personal pronoun "we".

1) We saw that work on the relations between language and society has given the title sociolinguistics. (Text I: 58)

Kita telah melihat bahwa kajian tentang kaitan antara bahasa dan masyarakat dinamakan sosiolinguistik.

2) We keep them because we feel that the two queens seem to symbolize the character of their times. (Text III)

Kita tetap mempertahankan kedua istilah itu karena kita merasa bahwa kedua ratu itu menyimbolkan cirri-ciri dari zamannya.

3) To this end, we suggest that any content analysis must be performed relative to and justified in terms of the context of the data. (Text IV: 16)

Untuk tujuan ini, kami menegaskan bahwa analisis isi harus dilaksanakan berkaitan, dan dijustifikasi dalam hubungannya dengan konteks data.

4) We shall try to illustrate 'elaborative' and 'evaluative' inferences in the discussion of extract (61) later in this chapter. (Text V)

Akrn kami coba menggambarkan inferensi-inferensi 'elaboratif' dan 'evaluatif' dalam membicarakan kutipan (6I) padababini.

\section{E.2 Analysis on the Category of Tense}

The present tenses are the most common tenses used within the samples $(85 \%)$ considering these samples are taken from science books which usually describe or explain something.

It is known that the time reference of past, ptesent and future in English do not actually refer to the past time; present time and future time. In Bahasa Indonesia, however, these time references actually refer to the present time, past time, and future time. The analysis of the eight sample books found that the English present tenses, for instance, are not always translated into present forms in Bahasa 
Indonesia. The examples are mostly found in the case of Present.Perfect Tense. There are also past tenses which are not translated into past forms in Bahasa Indonesia. The following are the examples of the two cases found in the analysis of the sample books.

1) The nature of linguistic abstractions has already been discussed,... (Text I: 1 ) . Kita telah membahas hakikat abstraksi linguistis, ...

2) A number of important books have been published on it in recent years. (Text I: 43)

Pada tahun-tahun belakangan ini, sejumlah buku penting mengenai aspekaspek ini dalam linguistic telah diterbitkan.

3) They called this dependence on- external, non-literary assumptions 'motivation'. (Text VI: 8)

Mereka menyebutnya ketergantungan padakeadaan luar,pada asumsi-asumsi 'motivasi'yang non kesusastraan.

4) The theme of 'motivation' turned out to be important in a great deal of subsequent literary theory. (Text VI: 8 )

Tema 'motivasi' itu berubah menjadi penting dalam banyak teori sastra yang berikut.

5) During the preceding period some of thee questions were considered unanswerable and taboo, since raising them would have led to discussion and strife. (Text II: 2)

Pada masa dahulu, beberapa di antara issu tersebut tidak bias dijawab dan tabu, karena pasti akan menimbulkan diskusi hangat dan berbuntut perselisihan.

6) "The Maori believed that the original state of the universe was 'kore', a condition of chaos or nothingness permeated with generative powers. (Text VII: 17)

"Orang Maori percaya bahwa asal mula alam adalah kore, yaitu suatu keadaan khaos atau kosong yang diserapi oleh kekuatan-kekuatan yang generative.

These examples imply that the word telah or sudah to denote past time, the word sedang to denote present time, and the word akan to denote future time do not always fit the ideas of present tenses, present tenses, and future tenses. These three words denoting time reference (telah/sudah, sedang, akan) are applicable in the 
case of real past, real present, and the real future tenses. The following examples show the use of these words to denote the idea of real past, present and future tenses.

1) A similar point was made with regard to possible titles for discourse fragments. (Text VI: 22)

Hal yang serupa telah dikemukakan sebelumnya berkenaan dengan juduljudul yang mungkin untukpenggalan-penggalan wacana.

2) Suppose that Jack and Jill are walking down a lane. (Text II: 14)

Andaikan, Jack dan, Jill sedang berjalan melalui sebuah lorong.

3) We shall try to illustrate 'elaborative 'evaluative' inferences in the discussion of extract (61) later in this chapter. (Text V: 36)

Akan kami coba menggambarkain inferensi-inferensi 'elaboratif' dan 'evaluatif' dalam membicarakan kutipan (61) pada bab ini.

\section{E.3 Analysis on the Category of Voice}

Both English and Bahasa Indonesia have the category of voice but they do not always use it in the same frequency. The analysis of the sample books has found the fact that English active clauses are not always translated or expressed in Bahasa Indonesia with active clauses and the English passive clauses are not always translated into passive in Bahasa Indonesia. There are only a small number of active clauses which are not translated by using the active clauses in Bahasa Indonesia but rather by using the passive ones (less than 5\%).

The results of the analysis have shown that the English active clauses are mainly translated into passive clauses in Bahasa Indonesia whenever the intransitive verbs are used in the active clauses or when the emphasis of the clauses are on the actions rather than on the agent (or the 'doer') of the actions. There are also some passive clauses which are not translated by using the passive clauses in Bahasa Indonesia but rather by using the active ones (10\%). This is done mostly by making an inversion of the object or by replacing the subject with the inclusive first person plural form in Bahasa Indonesia, kita. This replacement of the subject, however, may result in the distortion of meaning since the emphasis of the clauses is no longer on the event but rather on the agent of the actions. The following are examples of English active and passive clauses together with their translations. 
1) Abstractions like plosive, bilabial; consonànt, noun, genitive case; etc apply. repeatedly to parts of utterances that must be referred lexically to... (Text I:4) Abstraksi seperti plosive, bilabial, konsonan, nomina, kasus genitive, dan sebagainya, diterapkan berulang kali pada bagian-bagian ujaan yang harus dikaitkan secara leksikal...

2) ... each can occupy a place after the and before a collocationally compatible member of the class of words... (Text I: 4)

Setiap kata tadi bisa ditempatkan dibelakang kata the dan di depan anggota kelaskata ...

3) The nature of linguistic abstraction has already been discussed,... (Text I: 1) Kita telah membahas hakikat abstraksi linguistis...

4) ...the ideal of objectivity should be abandoned by those engaged in comparative studies. (Text VII: 12)

...mereka yang menekuni penelitian-penelitian perbandingan dapat mengenyampingkan objektivitas.

\section{F. Conclusion}

The results of the analysis on the three grammatical categories are concluded as follows.

1) Most English personal pronouns with person reference are translated or encoded by the personal pronouns in Bahasa Indonesia, when these pronouns are used to refer to persons. Pronouns are not translated at all whenever their meanings are considered known from the context. English pronouns with person reference are translated into Bahasa Indonesia by using the repetition of the nouns when they are used to refer to non-personal reference.

2) The idea of tense in Bahasa Indonesia is not expressed morphologically but lexically by adding particular words that denote the time references of the verbs. The words denoting time references which are commonly used are. sudah, telah for past time, sedang for present time, and akan for future time. The use of these words do not always fit the ideas of past tenses, present tenses, and future tenses. These words are mainly applicable dealing with the real present, past or future tenses. 
3) Both English and Bahasa Indonesia have the category of voice. The English active and passive forms, however, do not always have the same forms in Bahasa Indonesia. The English active sentences are not always translated into active sentences in.Bahasa Indonesia, and vice versa.

\section{Bïbliography}

Baker, Mona. (1992). In Other Words: A Course Book on Translation. London: Routledge.

Baker, Mona (ed). (2001). Routledge Encyclopedia of Translation Studies. London: Routledge

Catford, J.C. (1965). A Linguistic Theory of Translation. London: Oxford University Press.

Frank, Marcella. (1972). Modern English: A Practical Reference Guide. New Jersey: Prentice-Hall. Inc.

Hatim, Basil and Jeremy Munday. (2004). Translation: An Advanced Resource Book. London: Routledge.

Hornby, AS. (1975). Guide to Patterns and Usage in English. Oxford: Oxford University Press.

Moeliono, Anton.(1988). Tata Bahasa Baku Bahasa Indonesia. Jakarta: Balai Pustaka.

Newmark, P. (1988). A Textbook of Translation. London: Prentice Hall International.

Purwo, Bambang Kaswanti (ed). (1986). Pusparagam Linguistik dan Pengajaran Bahasa. Jakarta: Arcan.

Quirk, Randolf and Sidney Greenbaum. (1973). A University Grammar of English. England: Longman Group Limited.

Zuchridin, S. (1989). Terjemahan: Pengantar Teori dan Praktek. Jakarta: Gramedia Pustaka Utama. 